\title{
A KAPITALISTA VÁLLALAT GAZDASÁGTÖRTÉNETI ÉS VÁLLALATELMÉLETI MAGYARÁZATAI: ÁTTEKINTÉS ÉS KRITIKA
}

A kapitalista vállalat elsố formája a gyárüzem (factory) volt, amely az angol ipari forradalom nyomán fejlődött ki és terjedt el. A gyárüzem kialakulására vonatkozó magyarázatok két, egymástól elkülönültt diszciplína, a gazdaságtörténet és a vállalatelmélet keretében fejlódtek. A tanulmány bemutatja ezeket az elméleteket, majd kritikájukon keresztül a történeti vállalatelmélet szükségessége mellett érvel. A történeti vállalatelméleti perspektíva a gyárüzem tanulmányozása során nemcsak abban segít, hogy magyarázatot adjunk arra, miért alakult ki a kapitalista vállalat, de abban is, hogy feltárjuk a kapitalista vállalat megkülönböztető jegyét. A tanulmány felvázolja e megközelítés kereteit is.*

Kulcsszavak: gyárüzem, ipari forradalom, vállalatelmélet

A kapitalista vállalat, amelynek első formája a gyárüzem (factory) volt, az angol ipari forradalom nyomán vált a termelés domináns szervezeti formájává. A gyárüzem kapcsán a magyarázatok túlnyomó része a gazdaságtörténeti irodalomhoz kötődik, amely behatóan vizsgálja a gyárüzem kialakulásának és elterjedésének okait (,eredet” kérdés). Megközelítési módjával viszont természetszerúleg nem állítja középpontba a gyárüzem „természetének” megértését, ami a vállalatelmélet kérdésfelvetése. A vállalatelmélet azonban, elsốsorban a formális megközelítés dominanciájának köszönhetően, $a$ vállalatot magyarázza, s ezzel negligálja a történetiséget. Kétségtelen, hogy a vállalatelmélet első írásai (például Coase, 1937) tértôl és időtôl függetlenül magyarázták a vállalatok kialakulását, s a későbbiekben ez a történelmi szemléletet nélkülözó megközelítésmód meghatározóvá vált. Csak néhány szerző (Langlois, 1999: Leijonhufvud, 1986) próbálta történeti kontextusba ágyazva magyarázni a gyárüzem kialakulását.

E tanulmány célja az, hogy a gyárüzem kialakulását magyarázó gazdaságtörténeti és vállalatelméleti megközelítések áttekintésén és kritikáján át utat mutasson a történeti vállalatelméleti perspektíva szükségessége felé. E megközelítés kiindulópontként fogadja el azt a nézetet, miszerint a kapitalista vállalat történelmileg specifikus kategória (Hodgson, 2001), azaz konkrét történelmi kontextusban jött létre, így megértése nem nélkülözheti a történeti megközelítést. Ugyanakkor a kapitalista vállalat ,természetének”, azaz egyedi (megkülönböztetố) tulajdonságának is ki kell domborodnia az elemzésben. A történeti vállalatelméleti perspektíva tehát a gyárüzem tanulmányozása során nemcsak abban segít, hogy magyarázatot adjunk arra, miért alakult ki $a$ kapitalista vállalat, de abban is, hogy feltárjuk a kapitalista vállalat megkülönböztető jegyét.

A tanulmány a történeti vállalatelmélet kereteit vázolja fel, hiszen a hangsúly a létezô elméletek bemutatásán és kritikáján van; az elmélet részleteinek kifejtése külön tanulmányt igényelne. Azonban már a keretek felvázolása is egyértelmúvé teszi azt, hogy a gyárüzem pontosabb megértése a „természet” és az ,eredet” kérdések egyidejú megválaszolását igényli, $\mathrm{s}$ ehhez a két diszciplínának részben magáévá kell tennie a másik elemzési sajátosságait.

A tanulmány az alábbi szerkezetben épül fel. Az 1. rész bemutatja azt a termelési rendszert, amelyet a gyárüzem lassan elsorvadásra ítélt, és elemzi a gyárüzem elterjedésének folyamatát. A 2. rész összefoglalja 
a gyárüzem kialakulását magyarázó gazdaságtörténeti és vállalatelméleti elméleteket. A 3. rész az elméletek kritikáján keresztül a történeti vállalatelmélet mellett érvel. A 4. rész összefoglal.

\section{A gyárüzem uralkodó formává válása: történeti előzmények}

Az ipari forradalom elótti termelési rendszer a családi kézmúipar (cottage industry) volt, amely nagyrészt a bedolgozói rendszer (putting-out) ${ }^{1}$ keretében múködött. Ez már a középkor végétól uralkodott, elsôsorban a textiliparban, és egészen a 19. század elejéig a termelés meghatározó szervezeti formája volt.

Valójában a bedolgozói rendszer „,nagy termelési egységnek" volt tekinthetô abban az értelemben, hogy a kereskedő-vállalkozó (putter outer) sok, otthonában dolgozó kisiparossal dolgoztatott, s így egy kiterjedt hálózatot tartott fenn. A vállalkozó biztosította a tókét, elsôsorban a forgótókét, mert a fix tóke jelentéktelen volt (Marglin, 1974). A családi céget az iparos mester vezette, aki néhány tanonccal és családi kisegítővel dolgozott. A termelés egysége így a háztartás volt, azaz a lakóhely nem különült el a munkahelytól (Mokyr, 1993, 2002), és a munkamegosztás a családtagok között létezett. Az alapanyag, a szerszámok és a termékek a kereskedô-vállalkozó tulajdonában voltak, aki „kiszervezte” a munkát az otthonaikban dolgozó munkásoknak, és darabbért fizetett nekik. ${ }^{2}$ A bedolgozói rendszer tehát decentralizált termelési rendszer volt, amelyben a kisiparosok mai szóval alvállalkozói kapcsolatban álltak a kereskedô-vállalkozóval. A kereskedő-vállalkozó klasszikus esetben vállalkozói és menedzseri feladatokat is ellátott, azaz biztosította a tôkét, ellenốrizte a munkát, megszervezte a disztribúciót és az értékesítést (Magnusson, 1991).

A bedolgozói rendszer többféle gazdasági, társadalmi és kulturális közeghez képes volt alkalmazkodni: Angliában, Franciaországban, Németországban és Itáliában is hosszú ideig múködött. Az egyes helyeken a fő különbség abban állt, hogy a vállalkozó-kereskedő különbözố (fontosságú) szerepet játszott: kulcsfigura akkor volt, ha a termelés komolyabb beruházást igényelt.

Vállalatelméleti szempontból a bedolgozói rendszer nem tekinthetố vállalatnak, valójában az piaci szerződéseken nyugodott, még ha ezek a szerződések hosszú távúak voltak is. ${ }^{3}$ Az iparosmester maga hozta meg a termelési döntéseket és maga termelt, s a kereskedővel a terméket cserélte az alapanyagra (Cohen, 1981). A kereskedő nem rendelkezett autoritással az iparossal szemben, s következésképpen elsősorban piaci koordi- nációs eszközöket (például árak) alkalmazhatott az iparos ösztönzésére. A rendszer hátrányai értelemszerúen azzal kapcsolatosak, hogy olyan koordinációs eszközök (köztük a parancs), amelyek az autoritáson alapulnak, nem voltak jelen a kapcsolatban. Így viszonylag költséges volt a kereskedő számára a minôség ellenôrzése, sốt magát a termelési folyamatot nem is tudta ellenőrizni. A mesterek ebben a rendszerben növelhették jövedelmüket, ha „rontották” a minőséget, vagy kevesebb alapanyagot használtak fel (embezzlement). Az ügynök-megbízó probléma tehát ezt a rendszert is terhelte. A munkamegosztás fejlôdésével, a termék bonyolultságának növekedésével azonban egyre nagyobb ügynöki költségekkel szembesült a vállalkozó-kereskedő, ami „bomlasztotta” a rendszert.

A gyárüzem azonban nem egyik napról a másikra vált meghatározóvá az évszázadok óta uralkodó termelési formával szemben. Csak lassan és fokozatosan terjedt el, s szorította ki a háztartásban történő termelést. Ebben a folyamatban a bedolgozói rendszer és a gyárüzem hosszú ideig egymás mellett létezett, a gyárüzem csak mintegy százéves együttélés után vált uralkodó formává (Mokyr, 1993, 2002; Jones, 1987). Mindez azt jelenti, hogy a gyárüzem és a családi kézmúipar alternatív intézményi trajektóriák voltak, amelyek előnyösebbek lehettek a másiknál bizonyos kontextusokban. ${ }^{4}$

Mindenekelótt azonban érdemes leszögezni, hogy nem az ipari forradalom találta fel a gyárüzemet, az már korábban is létezett, az ipari forradalom csak átalakította és „elterjesztette” (Mokyr, 2002). Ebben az értelemben azonban a gyárüzem pusztán a sok munkást egy helyen foglalkoztató termelési egységet jelöli. Angliában ilyen üzemek már az ipari forradalmat megelőzó időszakban is léteztek (Geraghty, 2003). ${ }^{5}$ Ezek egyik típusát azok a tevékenységek képviselték, amelyek túl energiaigényesek voltak ahhoz, hogy a háztatásban végezzék óket, vagy a termelés mérete volt túl nagy. Ide tartoztak az üveggyárak, papírgyárak, sörfőzdék, kalapácsolóüzemek és a vasgyártás. A másik csoportba azok a nagy protofaktúrák (protofactories) sorolhatók, amelyekben sok munkás dolgozott hagyományos kézi technológiát használva. Ezekben a kézmúipari és az üzemi technológia nem különbözött egymástól, így a munkahely centralizálásának alapvetôen szervezeti okai voltak, hiszen a közvetlen ellenőrzésnek köszönhetően javítható volt a minőség-ellenôrzés és a munkavégzés intenzitása. Geraghty (2003) kifejti, hogy ezek a korai gyárak nem az ipari forradalom kiváltotta technológiai változásnak köszönhették létüket; az ilyen üzemek legkorábban a gyapjúipar egyes ágazataiban jöttek létre, például a kártolásban vagy a fehérítésben. 
A kapitalista vállalat „kritériumainak” ${ }^{6}$ megfelelő gyárak kialakulása is a textiliparban, ezen belül is a selyemiparban kezdődött. Thomas Lombe gyára volt az elsô, amely radikálisan szakított a protofaktúrák tulajdonságaival azáltal, hogy központi energiaforrást használt. ${ }^{7}$ Jones (1987) behatóan elemezve a gyárüzem elterjedését a brit selyemiparban meggyőzóen megmutatja, hogy azok elterjedése az ipari forradalom technológiai újításait követte. A gyárak elsố nagy hullámban 1732 után jelentek meg a selyemfonásban, amikor Thomas Lombe szabadalma lejárt. A szövésben lassabb volt a gyárak kialakulása és elterjedése: a Jacquard szövôszék 1822-es franciaországi feltalálása után átkerült Angliába, és a gyárak keretei közé kezdte kiszorítani a szövést is. A selyemiparban tehát viszonylag gyorsan haladt az üzemek előre törése, de sohasem vált teljessé abban az értelemben, hogy minden termelóegységre kiterjedt volna (Jones, 1987).

A textilipar többi ágazatában sokkal kevésbé volt látványos a gyárak elterjedése. Az átalakulás során elsóként egy vegyes rendszer alakult ki, jellemző volt erre a gyapjúipar. Itt bizonyos termelési tevékenységeket „kiszerveztek” az otthonaikban dolgozó iparosoknak, míg a termelés maradék része már a gyárüzemben folyt. ${ }^{8}$ Bár a gyárak elszaporodását a textiliparban „drámainak" szokás minősíteni, de még itt is egy évszázad vagy még hosszabb idô kellett ahhoz, hogy teljessé váljon (Mokyr, 2002). ${ }^{9}$

A textilipar mellett a többi iparág is az „üzemesedés" útjára lépett Angliában. A vasgyártásban két fontos innováció hozott változást a termelés méretében és szervezetében: a kokszolvasztás és a hengerlés. A kokszolvasztás nagyon tókeigényes tevékenység volt, így növelte a minimálisan hatékony üzemméretet. A hengerlés pedig szünet nélküli termelési folyamatot követelt meg. A fémiparban gôzgépeket használtak és nagy volumenben termeltek. A kerámiaiparban is korán kezdtek elterjedni a gyárak: Josian Wedgwood alkalmazott elsóként nagyüzemi termelést, innovatív termelési technológiát és gôzenergiát (Geraghty, 2003). A 19. század közepéig a gyárak száma gyorsan nőtt, 1860-ra Angliában a gépesítés egyfajta ipari dualizmust hozott létre (Geraghty, 2003).

\section{Magyarázatok}

Mivel a gyárüzem elszaporodása összefonódik az ipari forradalommal, természetes, hogy a gazdaságtörténeti megközelítésú magyarázatok meghatározó helyet foglalnak el a gyárüzem kialakulását magyarázó elméletek között. A hagyományos gazdaságtörténet az ipari forradalom hozta új technológia kulcsszerepét hangsúlyoz- za (Mantoux, 1961; Landes, 1986; Mokyr, 2002; Jones, 1982, 1987): „A nagyüzemi rendszer a gépek alkalmazásának szükségszerú következménye volt" (Mantoux, 1961: 252. o.). Másrészt, a gazdaságtörténeti elméletek között figyelmet érdemel a marxi megközelítésú nézet, amely a munka kizsákmányolásán keresztül magyaráz (Marglin, 1974).

Sajátos helyet foglalnak el az elméletek között azok, amelyek a gazdaságtörténeti megközelítést vállalatelméleti aspektusokkal ötvözik. Ezek között elsố helyen kell említeni Mokyr (2002) elméletét, amely lényegesen árnyalja a hagyományos gazdaságtörténet ,,a technológia számít" nézetét. Szerinte ugyanis nem egyszerúen csak az új technológia, hanem a technológia jellege számít: az ipari forradalom új technológiája rendkívüli mértékben megnövelte a speciális szaktudású munkások iránti igényt, akiknek a tudását hatékonyabb volt a vállalaton belül koordinálni. Geraghty (2007) teóriája pedig Milgrom és Roberts (1990) vállalati tevékenységek komplementaritására vonatkozó nézetére épül.

A gyárüzem vállalatelméleti megközelítései között az egyik ág szintén a technológiai változásokkal magyaráz. A legjelentősebb ezek között a csoporttermelés okozta aszimmetrikus információs problémához kapcsolódik (Alchian - Demsetz, 1972; Langlois, 1999). A vállalatelméleti magyarázatok egy másik köre nem a technológiának, hanem a tranzakciós költségeknek tulajdonít szerepet a gyárüzem kialakulásában. Ezek között jelentôs magyarázat Williamson $(1980,1985)$ és North (1982) elmélete.

\section{A hagyományos gazdaságtörténet magyarázata: fix költség és skálahozadék}

A hagyományos gazdaságtörténeti megközelítésben a gyárüzem a technológiai változások, azaz a drága gépek és a központi energiaforrás használatának eredménye. A gépesítés valójában a lekötött tókét növelte meg, s ez pedig lényegesen megnövelte a hatékony üzemméret minimális szintjét azáltal, hogy növekvô skálahozadékot eredményezett (Mantoux, 1961; Landes, 1986).

Az optimális üzemméret megnövekedése nagyrészt tehát az ipari forradalom hozta új berendezések használatának következménye volt. ${ }^{10}$ Ezeket a vasgyártásban vagy vegyiparban használatos gépeket nem is lehetett volna kis termelési méret esetén hatékonyan használni. Ugyanakkor a fútés, a világítás, az energiaellátás és a biztonság is azok közé a tevékenységek közé tartoztak, amelyeknél a nagyobb üzemben érvényesül a méretgazdaságosság. Harmadrészt pedig a marketing és a pénzügyek is költségelőnyökkel járnak nagyobb termelési volumen esetén, s így nem csak technológiai jellegú növekvố skálahozadékkal lehetett számolni. Mindezeken 
kívül Landes (1986) a kiterjedtebb specializáció szerepét is hangsúlyozza abban, hogy a gyárüzem költséghatékonyabb formává vált a bedolgozói rendszerhez képest. ${ }^{11}$

A technológia „mindenható” szerepét hangsúlyozó elméleteket több szempontból is kritizálni lehet. Leijonhufvud (1986) szerint, jóllehet a méretgazdaságosság, s így a technológia fontos szerepet játszott a gyárüzem kialakulásában, az nem magyarázza meg teljesen annak kialakulását, hiszen sok munkaerốt egy helyen foglalkoztató üzemek az ipari forradalom elótt is léteztek, ahogy arról fentebb már volt szó. Például nagy gyapjúfeldolgozó üzemek és bányák már a 16. század eleje óta múködtek Angliában, s ezek méretét nem elsôsorban a technológia „diktálta”. Cohen (1981) szintén azt hangsúlyozza, hogy a gépek használata önmagában nem magyarázza meg az üzem kialakulását; a gépek sokkal inkább csak a (már létezô) üzem elterjedéséhez járultak hozzá azáltal, hogy csökkentették a termelési költséget. Pollard (1964) pedig egyenesen eltúlzottnak tartja a fix tóke szerepére vonatkozó érveket. Bár az ipari forradalomban egyes iparágakban valóban megnőtt a fix tốke aránya a forgótókéhez képest, 1780 és 1830 között egy tipikus gyárban ez még mindig alig volt több mint 50\% (Pollard, 1964: 302. o.). Valójában a tốkefinanszírozási problémák sokkal inkább a forgótőkével voltak kapcsolatosak ${ }^{12}$, következésképpen nem a gyárüzem sajátos problémáját jelentették: a bedolgozói rendszert is hasonló problémák jellemezték már a gyárüzem megjelenése előtti időszakban is.

\section{A munka kizsákmányolása}

A gyárüzem létrejöttét magyarázó elméletek között nem hiányzik a marxi megközelítés sem. A marxi elmélet szerint a darabbér alacsonyabb, mint a munka határterméke, s ez profit forrása. Ebben a gondolati keretben tovább lépve Marglin (1974) azt állítja, hogy a nagyüzemekben bevezetett munkakultúra és felügyelet nem az új technológiához való alkalmazkodással magyarázható, hanem a profit további növelésének szándékával. Vagyis a gyártulajdonosok azért hozták létre a hierarchiát, mert ez volt a legmegfelelóbb eszköz a munkások kizsákmányolásán keresztül a profit növelésére. A gyárüzem tehát arra szolgált, hogy a gyártulajdonos számára nagyobb részt biztosítson a „tortából”. Ennek megfelelően nem a technológiai hatékonyságot szolgálja, hanem a tókefelhalmozást. Az érvelésében tehát az új technológia semmilyen szerepet nem kap, sốt Marglin (1974: 89. o.) valójában megfordított érvelést használ: nem a technológiai változások vezettek a gyárüzem megjelenéséhez, hanem sokkal inkább a gyárüzem megjelenése és szervezete alakította a technológiai változásokat. ${ }^{13}$
Marglin (1974) perspektívájában az üzem kialakulása nem tekinthető történelmi szükségszerúségnek, sôt az technikai értelemben sem felső́bbrendú más szervezeti megoldásokkal szemben. Az üzem nem más, mint a munkafolyamat feletti ellenôrzés megszerzésének eszköze. Ez azt is jelenti, hogy az üzem elvette a munkásoktól a munkafolyamat ellenôrzésének jogát. ${ }^{14}$

Az persze nem vitatható, hogy a gyárüzem, ha már egyszer létezett, alkalmas „eszköz” volt a költségek csökkentésén keresztül akár a munka marglini értelemben vett kizsákmányolására is. Ahogy Jones (1987) is rámutat, a költségek csökkentésére többféle lehetôséget is kínált a gyárüzem, egyrészt, mivel a tóke „hatalma” nôtt a munka ellenében, a gyártulajdonos önkényesen növelhette a munkaidôt. Másrészt, a szigorú ellenőrzés következtében a munkások kevesebbet tudtak az alapanyagból „eltulajdonítani”. Harmadrészt, a gyáros olcsó munkaerốt, például gyerekeket is alkalmazhatott. A fentiek azonban a gyárüzem léte miatti lehetőségek voltak, s nem az üzem kialakulásának okai. Marglin érvelésében úgy túnik tehát, hogy az ok és az okozat felcserélődött.

Természetesen azt Marglin sem állítja, hogy a hierarchiát a gyártulajdonosok (capitalists) találták volna fel, hiszen az a prekapitalista termelésben is megfigyelhetô volt. Ez utóbbi azonban szerinte három lényeges szempontból is különbözött a gyárüzemen belüli hierarchiától. Először is a csúcson ugyanúgy egy termelő (mester) állt, mint alul (tanonc), akik együtt dolgoztak. Másodszor, a prekapitalista hierarchia lineáris volt, $\mathrm{s}$ nem piramis alakú. Harmadszor, a mester maga értékesítette termékét, közte és a piac között nem volt közvetítő. Az nem világos, hogy pusztán e három tulajdonság alapján miért kellene a prekapitalista hierarchiát kevésbé „kizsákmányolónak” tekinteni.

\section{A tudás növekedése}

A gyárüzem létrejöttét az új technológiával magyarázó gazdaságtörténeti megközelítésú elméletek között központi helyet foglal el Mokyr (2002) elmélete. Mokyr nem önmagában a technológia, hanem a technológia jellegének szerepét hangsúlyozza: az ipari forradalom találmányainak használata rendkívüli mértékben megnövelte a technikai-múszaki tudás iránti igényt. Ez azt jelenti, hogy az új gépeket az iparosmesterek nem tudták volna hatékonyan üzemeltetni, egyszerúen azért, mert nem rendelkeztek megfelelő múszaki ismeretekkel. Azaz amíg a termelés tudásigénye kicsi volt, addig a termelés kerete a háztartás volt.

Mokyr szerint a gyárüzem azért jött létre, mert az új (modern) technika múködtetése specializált tudást igényelt, nevezetesen szakértóket, mérnököket, gépésze- 
ket, vegyészeket, akik ellenőrizni és irányítani tudták a munkásokat, s akiknek az alkalmazása csak az üzemen belül volt lehetséges. Ilyen szaktudás 1760 után egyre több iparágban a háztartásban már nem volt elérhetô (Mokyr, 2002).

A gépek használata nyomán az egész termelési folyamat komplexebbé vált, ami a munkamegosztás gyáron belüli kiszélesedéséhez vezetett: minden egyén egy feladatra specializálódott, növelve ezzel a tudás szétszórtságát. Ahogy Hayek (1945) nagy hatású cikkében kifejtette, a szétszórt tudás leghatékonyabb koordinációját az árrendszer biztosítja. Azonban az ipari forradalom találmányai nyomán szükségessé vált nagyobb egyéni specializált tudást nagyon szoros komplementaritás jellemezte, s ez a hayeki megoldástól eltérô koordinációt igényelt: mivel a termeléshez sok egyén specializált tudására volt szükség, így a szétszórt tudás koordinálása a szoros komplementaritás miatt a piacon nem volt megvalósítható. A gyárüzem előnye tehát éppen abban állt, hogy lehetővé tette és elősegítette a tudás megosztását a vállalaton belül, s ebben a menedzsment kiemelkedő szerepet játszott.

A tudás koordinálása természetesen koordinációs költségekkel jár (Becker - Murphy, 1992) ${ }^{15}$ : a menedzsmentnek biztosítania kell, hogy minden egyén „eljuttassa” tudását ahhoz az egyénhez, akinek erre a termelésben szüksége van. Az üzem éppen azért jött létre, mert hatékony megoldást jelentett erre a problémára. A gyárüzemben azáltal, hogy koncentrálódott a múszaki tudás, csökkent az egyes munkások mások tudásához való hozzájutásának, azaz a koordinációnak a költsége. A nagy gyárak tehát nemcsak specializációra „kényszerítették” az egyéneket, de egyben biztosították a tudás koordinálását is a gyáron belül. Ezt a nézetet Becker és Murphy (1992) megállapítása támasztja alá, miszerint a specializáció mértékét nem a piac mérete korlátozza, ahogy azt Adam Smith gondolta, hanem a koordinációs költségek. ${ }^{16}$

A bedolgozói rendszert tehát Mokyr (2002) szerint a fenti okok miatt váltotta fel a gyárüzem, amely „egy tetô alá hozta” a munkásokat, specializációra „kényszerítette” óket és koordinálta a közöttük lezajló tudáscserét. Az üzem tehát egy alkalmas hely volt az egyéni implicit (tacit) tudás koordinálásának hatékony megvalósítására, valamint képezni is tudta specialistáit.

Mokyr elmélete az új technológia által igényelt újfajta tudáskoordinációs igényt állítja a magyarázat középpontjába, s ezzel szorosan kötődik a vállalat tudásalapú elméleteihez. Kiinduló kérdésfeltevése nem pusztán az volt, hogy miért jött létre a gyárüzem, hanem sokkal inkább az, hogy miért éppen az ipari forradalom adott lökést annak a folyamatnak, amely a gyárak elterjedését és meghatározó termelési formává válását hozta magával. E kérdésre adott válasza pedig elkerülhetetlenül elvitte a vállalatelméleti „látásmód” felé.

\section{Komplementer hatás}

A gyárüzem létrejöttét magyarázó elméletek között Geraghty (2007) nézeteinek kiindulópontja Milgrom és Roberts (1990) nézete az ún. komplementer hatásról. A két szerzô a komplementer hatást tágan értelmezi, úgy, mint különbözố tevékenységcsoportok közti kapcsolatot: ha a tevékenységek egy bizonyos körének volumene nó, ez növeli a marginális megtérülést a maradék tevékenységek esetében. A komplementer hatás pedig befolyásolja a termelés hatékony szervezeti megoldását. Általánosságban megállapítható, hogy a komplementer hatás a tevékenységek szoros koordinációját igényli (Milgrom - Roberts, 1990). Geraghty (2007) azt vizsgálja, hogy mi volt ennek a kölcsönhatásnak a konkrét tartalma az ipari forradalomban.

Először is, szerinte az üzem három komplementer tevékenységet fogott össze: a gépekbe történó beruházásokat, a szervezeti innovációkat (a folyamatok közvetlen felügyelete, szabályok, új bérezési rendszer), a minőség-ellenőrzés javítása. Milgrom és Roberts (1990) értelmében ezek közül bármelyik alkalmazása megnövelte a másik kettô alkalmazásából származó marginális megtérülést. Ennek megfelelően a gyártulajdonos nemcsak azért vezette be a monitoring tevékenységet, hogy nagyobb erőfeszítésre ösztönözze a munkásokat, hanem azért is, mert ez pozitív hatással volt a minőség-ellenőrzésre és a gépek karbantartására is.

A komplementer hatás elmélete szerint alapvetôen a technológiai változások „ösztönzik” a vállalkozókat a termelés nagyüzemi megszervezésére. Mivel a technológiai változások nem folyamatosak, Geraghty (2007) tesztelte, hogy egy-egy technológiai töréspont után vajon növekedett-e a gyárüzemek elterjedtsége. ${ }^{17}$ Empirikus vizsgálatában megmutatta, hogy a technológiai töréspontok után az üzemek fokozottabb mértékben alkalmazták a monitoring tevékenységet és a minőség-ellenőrzést. Ez a tény alátámasztja azt a nézetet, miszerint a jobb gépekben megtestesüló új technológia elterjedését erósítették a komplementer kapcsolatok. A legerósebb komplementer kapcsolatot a szervezeti innovációk és a gépesítés, valamint a szervezeti innovációk és a minőség-ellenőrzés között találta.

Geraghty (2007) nézetei azonban sokkal inkább a gyárüzem elterjedését magyarázzák, mintsem magának az üzemnek a kialakulását. 


\section{Csoporttermelés}

A gyárüzemet magyarázó vállalatelméletek meghatározó elmélete az Alchian és Demsetz (1972) által leírt csoporttermelés (team production) probléma oldaláról érvel a nagyüzem kialakulása mellett. A csoporttermelés olyan termelés, amelyben legalább két input vesz részt, az output nem a részt vevő inputokkal elő́lllított outputok egyszerú összege, és nem minden input ugyanannak az egyénnek a tulajdonában van (Alchian Demsetz, 1972: 779. o.). A csoporttermelésben tehát az egyének munkája egymást kiegészítő inputnak tekinthetô, valamint az egyéni határtermék mérése nagyon költséges. Ez lehetóséget teremt a csalásra (shirking), s az ún. potyázási problémához vezet. Ahogy Alchian és Demsetz (1972) leírják, itt valójában egy aszimmetrikus információs helyzettel (ügynök-megbízó probléma) állunk szemben. Alchian és Demsetz (1972) szerint a probléma úgy oldható meg, hogy az egyik egyén specializálódik az ellenőrzésre (monitoring), aki azzal válik érdekeltté a többiek tevékenységének optimális szintú ellenőrzésére, hogy megkapja a jogot a maradványjövedelemre. Az információs aszimmetria problémájának megoldása tehát a vállalat megszervezéséhez vezet, amelyben a termelési folyamat, s ezen keresztül a munkások tevékenységének ellenőrzése kulcsfontosságú tevékenységgé válik.

A határtermék mérésének nehézkessége ugyanakkor a munkások újfajta bérezéséhez, nevezetesen az idóbér alkalmazásához vezetett. ${ }^{18}$ Világos, hogy a bedolgozói rendszerben, amelyben a munkások otthonaikban dolgoztak, s így ellenőrzésük nem volt lehetséges, nem lehetett idóbért fizetni. ${ }^{19}$ Ebben a rendszerben valójában nagy erejú ösztönzók múködtek, mert a bér szoros kapcsolatban állt a teljesítménnyel, s így valószínúleg minden mester a számára optimális erőfeszítést tette. ${ }^{20}$ A gyárüzemben a darabbér alkalmazása esetén a gyártulajdonos a minőségbiztosítás okán magasabb költségekkel szembesült volna, míg az idóbér fizetése hatékonyabb volt, mert közvetlenül ellenórizhette magát a munkafolyamatot, azaz azt, hogy mi történik az üzemben. ${ }^{21}$ Ez a közvetlen felügyelet azt is lehetóvé tette, hogy a gyártulajdonos a drága gépek és berendezések szakszerú használatát kontrollálhassa. A bedolgozói rendszerben természetes módon problémát okozott az, hogy a vállalkozó nem tudta ellenőrizni, hogy a tulajdonában lévố eszközökkel hogyan bánt a mester.

Langlois (1999) arra is felhívja a figyelmet, hogy ha a monitoring tevékenység nem túl költséges, akkor előnyösebb darabbért fizetni. De ha a monitoring magas költségekkel jár, akkor a felügyelet (supervision) gazdaságosabb lesz, feltéve, hogy a piac mérete nőtt. ${ }^{22}$ A monitoring tevékenység mellett a csoporttermelés a gyártulajdonos koordináló tevékenységét is nélkülözhetetlenné tette. A csoporttermelés ugyanis nagyobb specializációhoz és a termékek standardizálásához vezetett (Langlois, 1999), ami az egyéni tevékenységek koordinálását, valamint az inputok idóbeli illesztését követelte meg.

Észre kell vennünk azonban, hogy a csoporttermeléshez kapcsolódó érvelés is technológiai alapú. Maga az új technológia, a gépesítés változtatta meg a termelés jellegét úgy, hogy a kiterjedtebb specializáció nyomán csoporttermelés alakult ki. Tehát a gyárüzem kialakulásának végső oka a technológiai változásokban keresendő.

\section{Tranzakciós költségek}

A gyárüzem létrejöttét magyarázó elméletek között feltétlenül kiemelendő a tranzakciós költség alapú magyarázat, amely nem a technológiának, hanem a tranzakciós költségeknek tulajdonítja a kulcsszerepet. Egész pontosan, az elmélet a gyárüzem létét azzal hozza öszszefüggésbe, hogy a piaci tranzakciók egy részének a hierarchia kereteibe történó bevonása bizonyos fajta költségek, nevezetesen a tranzakciós költségek csökkenését eredményezi (Williamson, 1980). Williamson szerint a gyárüzem alacsonyabb tranzakciós költségekkel „dolgozik”, ezért eredendően hatékonyabb, mint a bedolgozói rendszer. ${ }^{23}$ Magyarázatában a technológiának nincs szerepe, a gyárüzem akkor is hatékonyabb a bedolgozói rendszerrel szemben, ha a technológia maga lehetôvé tenné a nagyüzemi és a háziipari termelést is.

Williamson $(1980,1985)$ tehát hatékonysági szempontból hasonlítja össze a gyárüzemet a bedolgozói rendszerrel. Az összehasonlítás logikája az, hogy a termelést általában többféle módon is meg lehet(ne) szervezni: az alternatív szervezeti struktúrákban a termelés egymást követő fázisainak megszervezése eltérô tranzakciós költségekkel jár. 11 kritérium mentén hasonlítja össze a gyárüzem és a bedolgozói rendszer tranzakciós költség szempontú hatékonyságát. Ezek a kritériumok három csoportba sorolhatók:

1) termékáramláshoz kapcsolódó kritériumok - szállítási költségek: a termelés közbeni javak szállítása egyik munkaposztról a másikra,

- raktárkészlet: az egymást követô termelési fázisok által megkövetelt puffer készlet, interfészek miatti veszteség: a javak áramlás miatti termékvesztesége,

2) a munkafeladatok kijelölésének hatékonyságára vonatkozó kritériumok,

- munkaposzt: specializáció valamely munkafeladatra, 
- vezetés: az egymást követő fázisok koordinálása,

- szerződések: mennyire könnyú szerződni külsô specialistákkal,

3) ösztönzőrendszer tulajdonságaira vonatkozó kritériumok,

- munkaintenzitás: a munkás termelési erőfeszítése,

- berendezések használata: mennyire szakszerú és gondos a gépek használata,

- helyi sokkokra való reagálás: egy munkaposztot érintô váratlan eseményre való reagálás,

- helyi innováció: a munkafolyamat tökéletesítése egy adott munkaposzton,

- a rendszer alkalmazkodóképessége: mennyire képes a rendszer a sokkokra reagálni.

Az 1. táblázat tartalmazza az értékelést ${ }^{24}$, melyben összességében a bedolgozói rendszer alacsonyabb pontot kapott, mint az üzem, melynek legfóbb gyengesége változatlan" feltevés nem áll fent a két rendszer összehasonlításakor, ugyanis a munka sokkal olcsóbb volt a bedolgozói rendszerben, melynek okait részletesen elemzi cikkében. (2) Az értékelési rendszer túl durva ahhoz, hogy értelmes eredményre vezessen. Ennek kapcsán több ellenvetést fogalmaz meg. Elôször is, a termékáramlás tulajdonságainak nagyobb hatásuk van a költségekre, mint a másik két tulajdonságnak. Másodszor, a bivariáns pontozási rendszer nem elég árnyalt. Harmadszor, a pontszámok aggregálása is megkérdőjelezhető, mert a hatékonyság statikus és dinamikus aspektusait ötvözi egybe. (3) Maga a pontozás is több esetben megkérdőjelezhető. Jones (1982) szerint a 11 értékelési kritérium közül két esetben rosszul pontozott Williamson: a bedolgozói rendszer a raktárkészlet és az alkalmazkodóképesség terén is jobb. Mindezeken túl, Williamson nem nyújtott empirikus bizonyítékot hipotézisére, North pedig arra alapozza nézetét, ami intuitívan plauzibilis, és nem arra, ami történelmileg elfogadható (Jones, 1987).

1. táblázat

A bedolgozói rendszer és a gyárüzem hatékonyságának összehasonlítása

Forrás: Williamson (1985: 226. o.)

\begin{tabular}{|c|c|c|c|c|c|c|c|c|c|c|c|c|}
\hline \multicolumn{4}{|c|}{ Termékáramlás tulajdonságai } & \multicolumn{3}{|c|}{ Munkafeladatok kijelölése } & \multicolumn{6}{|c|}{ Ösztönzórendszer tulajdonságai } \\
\hline & $\begin{array}{l}\text { szállítási } \\
\text { költsé- } \\
\text { gek }\end{array}$ & $\begin{array}{l}\text { raktár- } \\
\text { készlet }\end{array}$ & $\begin{array}{c}\text { inter- } \\
\text { fészek } \\
\text { miatti } \\
\text { veszteség }\end{array}$ & $\begin{array}{c}\text { munka- } \\
\text { poszt }\end{array}$ & vezetés & $\begin{array}{l}\text { szerzó- } \\
\text { dések }\end{array}$ & $\begin{array}{c}\text { munka } \\
\text { intenzi- } \\
\text { tás }\end{array}$ & $\begin{array}{c}\text { beren- } \\
\text { dezések } \\
\text { haszná- } \\
\text { lata }\end{array}$ & $\begin{array}{c}\text { helyi } \\
\text { sokkokra } \\
\text { való } \\
\text { reagálás }\end{array}$ & $\begin{array}{l}\text { helyi } \\
\text { innová- } \\
\text { ció }\end{array}$ & $\begin{array}{c}\text { a } \\
\text { rendszer } \\
\text { alkalmaz- } \\
\text { kodó } \\
\text { képessége }\end{array}$ & $\begin{array}{l}\text { pont- } \\
\text { szám }\end{array}$ \\
\hline $\begin{array}{l}\text { Bedolgozói } \\
\text { rendszer }\end{array}$ & 0 & 0 & 0 & 1 & 1 & 0 & 1 & 1 & 0 & 1 & 0 & 5 \\
\hline Gyárüzem & 1 & 1 & 1 & 1 & 1 & 1 & 0 & 1 & 1 & 0 & 1 & 9 \\
\hline
\end{tabular}

A 0 érték alacsony hatékonyságot, az 1-es érték magas hatékonyságot jelöl.

Williamson szerint ${ }^{25}$ a termékáramlásban mutatkozott. A hierarchikusan szerveződő üzem jobb minőség-ellenórzést valósít meg, csökkenti a raktárkészletet, olcsóbbá teszi a szállítást és hatékonyabban allokálja a munkát. Végül is tehát Williamson azt mutatta meg, hogy a termelés hierarchikus szerveződése (gyárüzem) hatékonyabb a nem hierarchikus formáknál. ${ }^{26} \mathrm{~A}$ tranzakciós költség alapú érvelést North (1982) is hangsúlyozza: a gyárüzem elterjedésének az első lökést az adta, hogy a kereskedő szerette volna jobban ellenőrizni a termelési folyamatot, pontosabban a minôséget. ${ }^{27}$

Jones (1982) erősen kritizálja Williamson eljárását és következtetését. Ellenvetései három fô területre irányulnak: (1) Az a nézet, hogy a gyárüzem hatékonyabb szervezeti megoldás, mint a bedolgozói rendszer, a történelmileg nem igazolható ceteris paribus feltevésen nyugszik. Szerinte ugyanis a „minden egyéb

\section{A történeti vállalatelmélet felé}

Az angol ipari forradalom kapcsán a gazdaságtörténet által hangoztatott egyik legfontosabb stilizált tény az, hogy az ipari forradalom magával hozta a gyárüzemi (factory) rendszert. Ugyanakkor a vállalatelmélet pedig azt emeli ki, hogy a gyárüzemmel a kapitalista vállalat született meg. E két stilizált tény, jól érzékelhető módon, két különböző diszciplína elemzéseinek eredményeként áll eló. Az elemzésekben különböző kulcskérdések állnak a középpontban. A gazdaságtörténet arra a kérdésre keresi a választ, hogy miért alakult ki a gyárüzemi rendszer (,eredet” kérdés), míg a vállalatelmélet kulcskérdése az, hogy miben állt a gyárüzem lényege (,természet” kérdés). A két diszciplína alapvetően egymástól elkülönülten folytatja vizsgálódásait. Ahogy a fentiekben már szó volt róla, Mokyr és 
Geraghty magyarázatai azonban ötvözik a két terület megközelítésmódját. Bár mindketten gazdaságtörténészek, és kiindulópontjuk gazdaságtörténeti szemléletú, az érvelésben egy ponton mindketten vállalatelméleti meglátásokat is integrálnak a magyarázatba. Az alábbiakban magam is azt igyekszem megmutatni, hogy a gyárüzem pontosabb megértése a „természet” és az „eredet” kérdések egyidejü megválaszolását igényli. Ehhez a két diszciplínának részben magáévá kell tennie a másik elemzési sajátosságait.

Ami a vállalatelméletet illeti, a modern vállalatelmélet, elsôsorban a formális megközelítés dominanciájának köszönhetően, $a$ vállalatot magyarázza, s ezzel negligálja a történetiséget. A történeti szemléletmód hiánya világosan kirajzolódik a fent bemutatott elméletekben is: sem a csoporttermelés alapú, sem a tranzakciós költség alapú magyarázat nem épít az érvelésben arra a tényre, hogy a gyárüzem az ipari forradalom kontextusában alakult ki. Aligha lehet azonban vitatni, hogy a gyárüzem kialakulásának és természetének pontosabb megértése nem nélkülözheti a történetiséget a vállalatelmélet oldaláról sem. ${ }^{28} \mathrm{~A}$ vállalatelméleti elemzést tehát ki kell egészíteni gazdaságtörténeti „látásmóddal".

A gazdaságtörténeti magyarázatok, ahogy a fenti áttekintés is megvilágítja, alaposan feltárják és elemzik a gyárüzem tulajdonságait, úgymint a nagy volumenú termelés, a termelés centralizálása, a gépek használata, az új munkarend stb. Vállalatelméleti szempontból ezen elemzések legfontosabb hiányossága az, hogy nem világítanak rá a gyárüzem megkülönböztető tulajdonságára, azaz arra a jegyére, amely alapvetően mássá teszi azt a korábban létezố termelési formáktól. A gyárüzem ugyanis számos olyan ismérvvel (is) rendelkezett, amelyek nem kizárólagos jegyei voltak, hanem a korábbi szervezeti formákat is jellemezték. Éppen ezért a gyárüzem jellemzése, bár fontos feladat, nem azonos a gyárüzem lényegének megértésével.

$\mathrm{Az}$ ipari forradalom gazdaságtörténeti irodalma alapján a gyárüzem három lényeges jellemzôvel rendelkezett. Az egyik a korábban háztartásban dolgozó munkások ,egy tetố alatti” koncentrálása, azaz a centralizált termelés bevezetése a szétszórt, háztartásban folyó termelés helyett (Mokyr, 2002). Másrészt: radikális változás történt a termelési technikában: a termelési folyamat gépesítetté vált, ami növekvő skálahozadékot eredményezve lehetôvé tette a nagy volumenben történố termelést (Mantoux, 1961; Landes, 1986). Harmadrészt: a gyárüzem újfajta munkarendet (discipline) vezetett be (Geraghty, 2003; Pollard, 1963; McKendrick, 1961; Clark, 1994). A gazdaságtörténeti elméletek többnyire e tulajdonságok valamelyikét állítják érve- lésük középpontjába, s ezzel a gyárüzem egyik, nem feltétlenül kizárólagos tulajdonságán keresztül magyarázzák a gyárüzem kialakulását, $\mathrm{s}$ e jellemzố meglétét tekintik a gyárüzem sine qua nonjának. Az alábbiakban amellett fogok érvelni, hogy a gyárüzem e három tulajdonsága nem feltétlenül jelent „vállalatiságot”.

Ami a centralizált termelést illeti, maga Landes (1969: 14., 24. o.) is leírja, hogy a vasgyártásban, gépgyártásban, vegyiparban és hajógyártásban bár egy koncentrált helyen történt a termelés, azt nem vállalatszerúen szervezték meg: a szerszámok a munkások tulajdonában voltak, akik egyfajta alvállalkozóként dolgoztak. A centralizálás fó oka ezekben az esetekben az volt, hogy a gépek vagy a folyamat túlzottan nagyméretú és energiaigényes volt ahhoz, hogy a háztartásban végezzék. Elég egyszerúen arra gondolni, hogy bizonyos gépek fizikailag (méretük miatt) nem voltak használhatók a háztartásban (például sörfózés).

A nagy volumenú termelés szintén nem kizárólagos tulajdonsága a gyárüzemnek. Már az ipari forradalom elôtt is léteztek ,nagy” termelési egységek (Geraghty, 2003; Landes, 1969; Mokyr, 1993; Jones 1987), jó példát jelentenek erre a francia gobelinmanufaktúrák. De kézenfekvő példa a gyárüzemet megelőzôen létező bedolgozói (putting-out) rendszer is, amelyben sok vállalkozó-kereskedô nagy hálózatot tartott fent (Pollard, 1965). Ezek viszont a manufaktúrákkal együtt nem alkalmaztak gépeket. Ugyanakkor voltak az ipari forradalom idején kis mennyiségben termeló üzemek is (Landes, 1969). Másrészról azt, hogy a gépek használói nem kizárólag a gyárüzemek voltak, jól bizonyítja az, hogy a fonógépeket például kizárólag a háztartásokban használták (Mantoux, 1961). A fentiek fényében tehát tévedés lenne azt hinni, hogy a gyárüzem lényege csupán a nagy volumenú termelés volt.

A gazdaságtörténeti irodalom részletesen elemzi a gyártulajdonosok által bevezetett munkarendet és -kultúrát (factory discipline), s ezt a gyárüzem fontos jellemvonásának is tekinti (Geraghty, 2003; Pollard, 1963; McKendrick, 1961; Clark, 1994). A drága berendezések használata és a munkások között kulcsfontosságúvá vált koordináció egy sor szigorú rendszabályt követelt meg, például a kötött munkaidôt és a munkaidő pontos betartását. A kisebb gyárakban közvetlenül ellenôrizték a folyamatokat, valamint a munkások és a felügyelő személyes kontaktusa elégséges volt a szigorú munkarend fenntartására. A nagyobb üzemekben a közvetlen kommunikációt és ellenőrzést nem lehetett megvalósítani, ezért az üzem munkarendjét szabályokban fektették le. ${ }^{29} \mathrm{~A}$ felügyelet két formában valósulhatott meg (Geraghty, 2003). Ha sok képzett munkás dolgozott egy helyen, a tulajdonos sajátos alvállalkozói 
rendszert tartott fenn: a mester volt felelős saját munkásai felvételéért, felügyeletéért és fizetéséért, $\mathrm{s}$ ô határozta meg a munka intenzitását. Ugyancsak ô felelt a gépek üzembe állításáért és karbantartásáért. Ha képzetlen munkaerốt alkalmaztak, akkor általában a múvezetớk irányítottak, akik a menedzsment legalsó szintjét jelentették.

A szigorú munkarend (discipline) jelentős mértékben hozzájárult az állandó termékminőséghez, illetve a minőség javulásához a minőségi standardok (Magnusson, 1991), a minőség-ellenôrzés (Cohen, 1981) és a munkaeró gyáron belüli képzése ${ }^{30}$ (McKendrick, 1961) bevezetésén keresztül.

Látni kell azonban, hogy a szigorú munkarend bevezetésére a hierarchia és a hozzá szorosan kapcsolódó koordinációs mechanizmusok megjelenése adott lehetőséget, s így az következmény volt. Ebben az értelemben a munkarend önmagában nem volt a gyárüzem lényege.

A fent említett három tulajdonság, azaz a centralizált termelés, a nagy volumenú termelés és a szigorú munkarend tehát nem tekinthetốk a gyárüzem mint a kapitalista vállalat első formája sine qua nonjának. A gyárüzem pontosabb magyarázatához a vállalatelméleti és a gazdaságtörténeti megközelítést kell „összeolvasztani".

A vállalatelmélet oldaláról a magyarázatnak célszerú abból kiindulnia, amit a vállalatelmélet a vállalat megkülönböztetô jegyéról mond. A vállalat megkülönböztetô jegyének kérdése kiemelt figyelmet az utóbbi tíz évben kapott, amikor előtérbe került a vállalat elmosódó határainak kutatása a tudásgazdaságban. Ez az irodalom (pl. Foss, 2002; Kapás, 2004) a vállalat megkülönböztetô jegyének az autoritás dominanciáját tekinti a koordinációs eszközök között. A gazdaságtörténet oldaláról pedig abból a nézetból célszerú kiindulni, hogy az ipari forradalom lényege a technológiai változásban, pontosabban a makrotalálmányok felbukkanásában állt.

A kérdés ezek után az, hogy a radikális technológiai változások miként vezettek az autoritási alapon történő termelés kialakulásához. Azaz a történeti vállalatelméletnek azt kell megmutatnia, hogy az autoritás miért és hogyan vált elkerülhetetlenné a koordinációban a makrotalálmányok felbukkanása nyomán.

A mokyri makrotalálmányok soha nem látott mértékben kiszélesítették a piacot és kiterjesztették a munkamegosztást, ami jelentôsen növelte az új és jobb minôségú termékek iránti keresletet (Mantoux, 1961). Az új termékek, azaz a makrotalálmányoknak köszönhető termékek csak az új technológiával voltak termelhetốk, de a meglévố termékek tökéletesítése is megkö- vetelte az új technikát. Végeredményben az új és jobb minőségú termékek termelése másfajta (a bérmunka rendszerétól eltérô) monitoringot igényelt. Az újfajta monitoring, ahogy arról fentebb szó volt, a gyárüzemre jellemzó munkarend legfontosabb eleme volt, s az autoritáson alapult.

Mi jellemezte az újfajta monitoringot? A bedolgozói rendszerben múködố monitoring tevékenység két szempontból is különbözött a gyárüzemben alkalmazottól. Egyrészt: megváltozott a felügyelet tárgya. Míg a bedolgozói rendszerben a kereskedó-vállalkozó a terméket ellenőrizte, addig az üzemben már lehetséges volt magának a termelési folyamatnak az ellenőrzése. Másrészt: a gyárüzem megváltoztatta annak a személyét, aki az ellenőrzést végezte. Természetes módon a bedolgozói rendszerben, mivel a háztartásban folyt a termelés, a családfő ellenôrzött, míg az üzemben a gyártulajdonos.

Tehát a két rendszer különbsége nem abban állt, hogy az egyikben létezett monitoring, míg a másikban nem. Mindkét rendszerben múködött valamiféle monitoring, de a gyárüzem ennek jellegét drasztikusan megváltoztatta: a bedolgozói rendszer szerződéses (piaci) típusú felügyeletét hierarchián belülivé változtatta (Langlois, 1999), s ezzel vált vállalatszerúvé a monitoring. ${ }^{31}$ A történeti elemzés alapján tehát azt a következtetést lehet levonni, hogy a gyárüzem abban a tekintetben hozta a legfontosabb változást a bedolgozói rendszerhez képest, hogy megváltozott a monitoring természete. Ennek keretében az üzem olyan munkarendet (discipline) vezetett be, amely a munkásokat megfelelő szintú erófeszítésekre ösztönözte. A gyárüzem kialakulása tehát nem önmagában a monitoring (és a munkarend) bevezetését jelentette, hanem ezek jellegének megváltozását, vagyis a monitoring nem kizárólag a gyárüzem sajátossága volt (Cohen, 1981; Langlois 1999). A gyárüzem egyedi sajátossága abban állt, hogy az autoritáson alapuló monitoring a legfontosabb koordinációs eszközzé vált. A vállalatszerú monitoring pedig magával vonta a foglalkoztatási viszonyt: a gyárban a munkás eladta a munkaerejét egy bizonyos periódusra, és cserébe elfogadta a gyártulajdonos autoritását a munkarend, a felügyelet és a munkafolyamat megszervezése terén (Simon, 1951).

A fenti rövid érvelés tehát az ipari forradalom lényegét jelentố makrotalálmányok által indukált változások történeti nyomon követése után ,visszaérkezett” a vállalatelmélet megállapításához: a vállalat megkülönböztető jegye az autoritáson alapuló koordinációs eszközök dominanciája. S ezzel megmutatta azt a logikai szálat, amely a gyárüzem gazdaságtörténeti és vállalatelméleti magyarázatait összeköti. 


\section{Összefoglalás}

A tanulmányban a kapitalista vállalat elsô formáját, a gyárüzemet magyarázó elméleteket vettem górcsố alá. Részletesen áttekintettem a vonatkozó elméleteket, amelyek egyrészt a gazdaságtörténet, másrészt a vállalatelmélet keretében mozognak. Az irodalom áttekintése nyomán világosan kirajzolódott, hogy a két diszciplína eltérô kérdéseket állít a magyarázat középpontjába.

A gazdaságtörténet a gyárüzem „eredetét”, azaz kialakulásának történeti okait tárja fel. Ez a hatalmas irodalom az ipari forradalom történeti elemzésén keresztül magyarázza meg a gyárüzem kialakulásának körülményeit. Ezzel szemben a gyárüzemmel foglalkozó vállalatelméleti irodalom meglehetôsen szerény, s ráadásul kifejezetten a gyárüzemmel csak néhány írás foglalkozik. A gyárüzem ,természetére” vonatkozó nézetek döntố része a történeti megközelítést nélkülözó „általános” vállalatelméleti irodalomból olvasható ki.

Az elméletek kritikája nyomán amellett érveltem, hogy a gyárüzem pontosabb megértéséhez a gazdaságtörténeti és a vállalatelméleti megközelítésnek egyidejúleg érvényesülnie kell. Azaz, amikor történeti elemzésben tárjuk fel a gyárüzem kialakulását, különös figyelmet kell fordítani arra a tényre, hogy a gyárüzemmel $a$ (kapitalista) vállalat született meg. Így a gazdaságtörténeti érvelés során a kapitalista vállalat „természetének”, azaz egyedi (megkülönböztető) tulajdonságának is ki kell domborodnia az elemzésben. Ezt a megközelítést nyújtja a történeti vállalatelmélet, melynek kereteit vázoltam fel a tanulmányban, s amelynek kidolgozása további kutatást igényel.

\section{Lábjegyzet}

* A tanulmány megírását támogatta az OTKA (67713. számú szerződés) és az MTA Bolyai János Kutatási Ösztöndíja.

${ }^{1}$ A bedolgozói rendszer részletes leírásáról lásd: Landes (1966), Magnusson (1991).

${ }^{2}$ Természetesen voltak kisebb különbségek az egyes kereskedók gyakorlatában, de az alapanyagot minden esetben a kereskedó biztosította, és a termék is az övé volt. Néhány esetben viszont a szerszámok az iparosok tulajdonában voltak (Magnusson, 1991).

${ }^{3}$ A bedolgozói rendszer természetesen szervezetre jellemzó jegyekkel sem rendelkezett, ahogy azt Kieser (1994) is hangsúlyozza.

${ }^{4}$ Valójában a nagy volumenben termeló gyárak és a háztartásban dolgozó iparosok egy-egy szélső pólust képviseltek a termelési szervezetek terén. Európa sok részén (Lyon, Sheffield, ÉszakItália) olyan hálózatok alakultak ki, amelyekben a kisipari tevékenység kombinálódott a nagyüzemivel (Piore - Sabel, 1984).

${ }^{5}$ Lásd Pollard (1968) példáit.

${ }^{6}$ Hodgson (2001) érvelése szerint a kapitalista vállalat egy történelmileg specifikus kategória, amely az elózô korok vállalataitól eltéró jegyekkel is rendelkezik. Ezek a termelési eszközök magántulajdona és a munkások alkalmazása, azaz a foglalkoztatási viszony.

${ }^{7}$ Thomas Lombe 1718-ban Derby grófságban alapított selyemfonó gyára elsőként használt vízi energiát. 500 munkást foglalkoztatott és egy ötemeletes épületben múködött (Geraghty, 2003; Jones, 1987).

${ }^{8}$ A korai modern gyárak prototípusa volt Richard Arkwright gyapjúfonó üzeme az 1770-es években, amely vízi energiát használt, és az anyagok folyamatos áramlását biztosította az üzemen belül (continous flow) (Geraghty, 2003).

${ }^{9}$ A kontinens országaiban Angliához képest a gyárak kialakulása jelentôs késéssel ment végbe (Geraghty, 2003). Másrészt, az eltéró társadalmi-gazdasági-kulturális környezetnek köszönhetően maga a rendszer is nem elhanyagolható különbségeket mutatott. Kieser (1994) leírja, hogy Németországban például a gyárak kialakulása idején a gyenge oktatási rendszernek köszönhetően kevés volt a képzett munkaerő. Így a gyártulajdonosoknak kellett foglalkozniuk saját munkaerejük képzésével, s ez vezetett a fejlett tanoncrendszer kialakulásához.

${ }^{10}, \ldots$ a gyárüzemet nem az akarat, hanem az izom, vagyis a gépek tették sikeressé Angliában. Az üzem akkor jelent meg, amikor a gépek elterjedtek; ez volt az egyetlen lehetséges mód a szétszórt termelés költségelőnyének túlszárnyalására." (Landes, 1986: 607. o.)

${ }^{11}$ A specializáció kiterjedtségét jól érzékelteti a Wedgwood porcelángyárra vonatkozó adatsor: 1790-ben a gyár által alkalmazott 278 munkásból csak ötnek nem volt specializált feladata (McKendrick, 1961).

${ }^{12}$ Pollard (1964) hozzáteszi, hogy a fix tóke finanszírozása sokkal nehezebb volt, s így a közszolgáltatásokban (utak, csatornák) komolyabb volt a probléma.

${ }^{13}$ Természetesen az a nézet, hogy a gyárüzem kedvezett a további technológiai változásoknak helytálló, s az irodalomban is sokan hangsúlyozzák (például Szostak, 1989). De a tisztánlátás okán Mokyr (1990) nyomán célszerú különbséget tenni makro- és mikrotalálmányok között. Mokyr makrotalálmányoknak nevezi a jelentős technológiai fejlődést kiváltó, lökésszerúen felbukkanó találmányokat. Megtörve az addigi technikát, ezek eredendően új technikát honosítanak meg (például a gôzgép és a vasút az angol ipari forradalomban). Másutt (Kapás, 2007) már kifejtettem, hogy a gyárüzem mint új társadalmi technológia kedvezett a mikrotalálmányok felbukkanásának, amelyek tudatos (kutatásfejlesztési) erófeszítések eredményei. Amikor azonban arról van szó, hogy a technológiai változások magukkal hozták a gyárat, a makrotalálmányokra kell gondolni. Marglin feltehetóleg nem számol ezzel a kétféle technológiai változással, így állítása erôs kétségeket ébreszt.

${ }^{14}$ „... a munkások gyárüzemen belüli koncentrálódása semmilyen kapcsolatban nem állt a skálahozadék miatti technológiai elónyökkel. A gyárüzem sikerének és elterjedésének kulcsa abban állt, hogy a gyártulajdonos ellenőrizte a munkásokat; valamint a munkarend és a felügyelet csökkentette a költségeket még akkor is, ha az üzem technológiailag nem volt felsóbbrendú." (Marglin, 1974: 5. o.)

${ }^{15}$ A koordinációs költségek az ügynök-megbízó konfliktusból, a kizsákmányolási (hold-up) problémából és a kommunikációs nehézségekből erednek (Becker - Murphy, 1992).

${ }^{16}$ Becker és Murphy (1992) megmutatják, hogy a tudományos és egyéb tudás növekedése, párosulva a koordinációs költségek csökkenésével, nagyobb specializációhoz vezet. 
${ }^{17}$ A vizsgálatban kilenc különböző iparágban múködő összesen 75 üzem adataival dolgozott. Öt változóval ragadta meg a három komplementer tevékenységet.

${ }^{18}$ Cohen (1979) a piacitól eltérô bérezésben látja a vállalat megkülönböztető jegyét.

${ }^{19}$ Ráadásul mivel a termék homogén volt, a vállalkozó nem is volt érdekelt abban, hogy nagyobb erófeszítésre ösztönözze őket. A nem hatékony mesterek ugyanis kevesebb bért kaptak akkor is, ha darabbérben fizették óket.

${ }^{20}$ Ugyanakkor meg kell jegyezni, hogy bármennyire is megfelelönek mutatkozott a bedolgozói rendszerben a darabbér alkalmazása, mégis voltak nehézségek e téren is. Először is a mesterek magasabb jövedelemhez juthattak, ha kevesebb anyagot használtak fel a termelésben, vagy rontották a minőséget (embezzlement). (Erről részletesen lásd: Magnusson, 1991) Ez szintén a klasszikus ügynök-megbízó probléma egyik megnyilvánulása.

${ }^{21}$ Az idő- és a darabbér közötti választás feltételeinek kiváló elemzése található Lazear (1986) cikkében.

${ }^{22}$ Érdemes megjegyezni, hogy Langlois (1999) a piac méretének növekedésében látja az Alchian és Demsetz (1972) által leírt információs aszimmetria, s így gyárüzem megjelenésének okát. A piac méretének növekedése ugyanis növelte a termelési folyamat elôre jelezhetôségét és biztonságát, $\mathrm{s}$ mindez két hatás megjelenéséhez vezetett. Az egyik hatás a munkamegosztás hatása, a másik a volumenhatás. A munkamegosztás kiterjedtebbé vált: minden munkás egy szúkebb területre koncentrált. A volumenhatásnak köszönhetóen a termelésben tartósabb szerszámokat, gépeket, azaz lekötött tốkét kezdtek használni, ami magasabb fix költséghez vezetett. Ez pedig megnövelte a termelési folyamat ellenőrzéséból származó határelőnyöket (Langlois, 1999). Langlois szerint tehát a gyárüzem létrejöttének végső oka a piac méretének növekedésében keresendő.

${ }^{23}$ Elméletében ugyanis az a szervezeti struktúra a hatékonyabb, amelyik kisebb tranzakciós költségek mellett képes múködni, azaz a tranzakciós költségekkel való takarékoskodás a legfóbb szempont a szervezeti struktúra megválasztásában.

${ }^{24}$ Williamson értékelési rendszere a következő: minden kritérium esetén 0 vagy 1 lehet a pontszám, majd a pontszámok egyszerú összege adja a hatékonysági indexet.

${ }^{25}$ Jegyezzük meg, hogy a pontozást nem részletes elemzésre alapozta Williamson.

${ }^{26}$ Valójában Williamson (1980) 6 alternatív szervezeti módot hasonlított össze, ezek között a gyárüzemet és a bedolgozói rendszert.

27 „Az ipari forradalommal foglalkozó irodalom nagy része rossz helyre teszi a hangsúlyt - a technológiai változásból vezeti le a gyárüzem kialakulását, ahelyett hogy a centralizált üzemból vezetné le a felügyeletet, a nagyobb specializációt, az inputok jobb menedzsmentjét és a technológiai változást" (North, 1982: 168-169. o.).

${ }^{28}$ Kieser (1994) általánosságban is érvel amellett, hogy a vállalatelméletben miért van szükség történelmi elemzésre.

${ }^{29}$ A munkarend betartatása kezdetben elsôsorban az elrettentésen alapult (Pollard, 1963): testi fenyítés és elbocsátás. Késóbb a tulajdonosok pozitív ösztönzóket kezdtek használni, úgymint a termelékenységhez kötődő darabbér és bónuszok. A tulajdonosok azzal is igyekeztek elnyerni a munkások lojalitását, hogy különféle paternalista, fizetésen kívüli juttatásokat (lakás, betegségbiztosítás, balesetbiztosítás, orvosi ellátás, nyugdíj, oktatás stb.) biztosítottak.

${ }^{30}$ Mokyr (2002) hangsúlyozza, hogy a gyárüzem kialakulásától megváltozott a humán tóke képzése: a gyárüzem szerepet vállalt a képzésben a gyáron belül, de az iskolák támogatásán keresztül is.
${ }^{31}$ Érdemes megjegyezni azonban, hogy bizonyos esetekben a bedolgozói rendszerben is alkalmaztak „vállalatszerú” monitoringot, legalábbis abban az értelemben, hogy az ellenőrzésben hierarchia alakult ki. Ez olyan esetekben fordult elő, ha a bedolgozó kisiparosok száma túl nagy volt, ilyenkor a vállalkozó ,,alvállalkozókat" (sub-putter outer) alkalmazott, akik bizonyos számú kisiparossal álltak kapcsolatban (Kieser, 1994). Ez nem feltétlenül növelte a költségeket, mert az ,alvállalkozó” jobban tudta ellenórizni a mestereket.

\section{Felhasznált irodalom}

Alchian, A.A. - Demsetz, H. (1972): Production, Information Cost, and Economic Organization. American Economic Review 62. 5. p. 777-795.

Becker, G.S. - Murphy, K.M. (1992): The Division of Labor, Coordination Costs, and Knowledge. Quarterly Journal of Economics 107. 4. p. 1137-1161.

Berg, M. (1991): On the Origins of Capitalist Hierarchy. In: Gustafsson, B. (ed), Power and Economic Institutions: Reinterpretations in Economic History Aldershot: Edward Elgar. p. 173-194.

Clark, G. (1994): Factory Discipline. Journal of Economic History 54. 1. p. 128-163.

Coase, R.H. (1937): The Nature of the Firm. Economica 4. 16. p. 386-405.

Cohen, J.S. (1981): Managers and Machinery: An Analysis of the Rise of Factory Production. Australian Economic Papers June. p. 24-41.

Cohen, L.R. (1979): The Firm: A Revised Definition. Southern Economic Journal 46. 2. p. 580-590.

Foss, N.J. (2002): 'Coase vs Hayek': Authority and Firm Boundaries in the Knowledge Economy. International Journal of the Economics of Business 9. 1. p. 9-36.

Geraghty, T.M. (2003): Factory System. In: Mokyr, J. (ed), Oxford Encyclopedia of Economic History. Oxford: Oxford University Press

Geraghty, T.M. (2007): The Factory System in the British Industrial Revolution: A Complementarity Thesis. European Economic Review 51. 6. p. 1329-1350.

Hayek, F.A. (1945): The Use of Knowledge in Society. American Economic Review 35. 4. p. 519-530.

Hodgson, G.M. (2001): How Economics Forgot History: The Problem of Historical Specificity in Social Sciences. London, New York: Routledge

Jones, S.R.H. (1982): The Organization of Work. A Historical Dimension. Journal of Economic Behavior and Organization 3. 2-3. p. 117-137.

Jones, S.R.H. (1987): Technology, Transaction Costs, and the Transition to Factory Production in the British Silk Industry, 1700-1870. Journal of Economic History XLVII. 1. p. 71-95.

Kapás, J. (2004): Mutant-Firms in the New Economy. Economie et institutions 5. 2. p. 77-96.

Kapás J. (2007): Hogyan fejlődik a vállalat? A fizikai és a társadalmi technológia kölcsönhatásos evolúciós folyamata. Közgazdasági Szemle LIV. 1. p. 49-66. 
Kieser, A. (1994): Why Organization Theory Needs Historical Analyses and How This Should Be Performed. Organization Science 5. 4. p. 608-620.

Landes, D. (1969): The Unbound Prometheus: Technological and Industrial Development in Western Europe from 1750 to Present. Cambridge: Cambridge Universirty Press

Landes, D. S. (1966) (eds): The Rise of Capitalism, New York: Macmillan

Landes, D. S. (1986): What Do Bosses Really Do? Journal of Economic History 46. 3. p. 585-623.

Langlois, R.N. (1999): The Co-evolution of Technology and Organization in the Transition to Factory. In: Robertson, P. L. (ed), Authority and Control in Modern Industry, London: Routledge. p. 45-72.

Lazear, E.P. (1986): Salaries and Piece Rates. Journal of Business 59. 3. p. 405-431.

Leijonhufvud, A. (1986): Capitalism and the Factory System. In: Langlois, R. N. (ed), Economics as a Process. New York: Cambridge University Press. p. 203-223.

Magnusson, L. (1991): From Verlag to Factory: the Contest for Efficient Property Rights. In: Gustafsson, B. (ed), Power and Economic Institutions: Reinterpretations in Economic History Aldershot: Edward Elgar. p. 195-221.

Mantoux, P. (1961): The Industrial Revolution in the Eighteenth Century: An Outline of the Beginnings of the Modern Factory System in England. Chicago: University of Chicago Press. Revised Edition

Marglin, S.A. (1974): What Do Bosses Do? The Origin and Functions of Hierarchy in Capitalist Production. Review of Radical Political Economics 6. 2. p. 20-112.

McKendrick, N. (1961): Josian Wedgwood and Factory Discipline. In: Landes, D. S. (ed), The Rise of Capitalism. New York: Macmillan. 1966. p. 65-80.

Milgrom, P. - Roberts, J. (1990): The Economics of Modern Manufacturing: Technology, Strategy and Organization. American Economic Review 80. 3. p. 511-528.
Mokyr, J. (1990): The Lever of Riches: Technological Creativity and Economic Progress. New York, London: Oxford University Press

Mokyr, J. (1993): Editor's Introduction: The New Economic History and the Industrial Revolution. In: Mokyr, J. (ed), The British Industrial Revolution: An Economic Perspective. Boulder and Oxford: Westview Press. p. $1-127$.

Mokyr, J. (2002): The Gifts of Athena. Historical Origins of the Knowledge Economy. Princeton University Press

North, D.C. (1982): Structure and Change in Economic History. New York: W.W. Norton \& Co

Piore, M.J. - Sabel, C.F. (1984): The Second Industrial Divide: Possibilities for Prosperity. New York: Basic Books

Pollard, S. (1963): Factory Discipline and the Industrial Revolution. Economic History Review (New Series) 16. 2. p. 254-271.

Pollard, S. (1964): Fixed Capital and Industrial Revolution. Journal of Economic History 24. 3. p. 299-314.

Pollard, S. (1965): The Genesis of Modern Management. London: E. Arnold

Simon, H.A. (1951): A Formal Theory of the Employment Relationship. Ecometrica 19. 3. p. 293-305.

Szostak, R. (1989): The Organization of Work. The Emergence of the Factory Revisited. Journal of Economic Behavior and Organization 11. p. 343-58.

Williamson, O.E. (1980): The Organization of Work: A Comparative Institutional Assessment. Journal of Economic Behavior and Organization 1. 1. p. 5-38.

Williamson, O.E. (1985): The Economic Institutions of Capitalism. New York: Free Press

Cikk beérkezett: 2010. 3. hó

Lektori vélemény alapján véglegesítve: 2010. 4. hó

\section{E SZÁMUNK SZERZÖI}

Tuomo Alasoini, director, Tekes-Finnish Funding Agency for Technology and Innovation; Elise Ramstad, senior technology adviser, Tekes-Finnish Funding Agency for Technology and Innovation; Asko Heikkilä, senior technology adviser, Tekes-Finnish Funding Agency for Technology and Innovation; Pekka Ylöstalo, senior adviser, Finnish Ministry of Employment and the Economy; Dr. Kapás Judit, egyetemi tanár, tanszékvezetô, Debreceni Egyetem; Dr. Pitti Zoltán, tudományos kutató, Budapesti Corvinus Egyetem; Rózsa Andrea, egyetemi adjunktus, Debreceni Egyetem; Szóke Szabolcs, egy. hallgató, munkatárs, Budapesti Corvinus Egyetem, Pénzügykutató Zrt.-IKU Innováció Kutató Központ; Dr. Papanek Gábor, professzor emeritus; Sigér Fruzsina, tanársegéd, Debreceni Egyetem 